\title{
ELLIPSIS IN ENGLISH AND ALBANIAN
}

\section{MSc. Nesrin JAHJA}

Universum College, Department of English Language and Literature, jahjanesrin@gmail.com

\section{Article history:}

Submission 17 January 2021

Revision 19 March 2021

Accepted 10 April 2021

Available online 30 April 2021

\section{Keywords: \\ Cohesion, \\ Ellipsis, \\ Substitution, \\ Fiction, \\ Non-Fiction, \\ Nominal, \\ Verbal,}

Clausal.

DOI:

\begin{abstract}
A bst r a c t
This research attempted to conduct an in-depth analysis of the text-forming elements based on the fact that cohesive devices are insufficiently treated in the Albanian language, although considerable research and publications have been made in other languages.
\end{abstract}

This study aims to bring evidence in recognizing, determining, and categorizing the structures of ellipsis and substitution which perform in English and Albanian. Comparing these important elements of grammatical cohesion in two languages will bring light upon the differences and similarities between the two languages. It will also show how frequently they are used in English and Albanian. Particularly, the aim is to show how these two mechanisms enable the avoidance of repetition, either by choosing other short words, phrases, and clauses or by removal of words, phrases, and clauses.

This study involved samples of fiction and non-fiction texts of English and Albanian language, consisting of two novels and two daily newspapers. The findings of the research indicate that in fiction texts, ellipsis is used more in the Albanian language rather than in English whereas substitution prevails more in English than Albanian. Ellipsis is used more in the Albanian language rather than in English in non-fiction texts too. Nevertheless, the frequency of substitution seems to be the same in both languages with a total of 4 items in English and 3 items in Albanian.

\section{Introduction}

In everyday discourse, written or spoken, we rarely communicate with fully completed sentences. Normally, our messages contain many sentences which are structured according to defined linguistic rules. For this reason, in today's linguistics, there is a unit of language which is being discussed increasingly and it is beyond sentence length. That is the word text which constitutes the primary linguistic tool in discourse. (Dibra, 1995) Language is a means of communication that requires constant study in both its written and spoken form. Generally speaking, it is a system made of gaps in which the speakers and writers operate within the context by omitting and replacing parts of linguistic structures. Moreover, the omitted and replaced linguistic structures are understood even though they are not expressed. The study of grammatical devices is a major area of interest within the field of linguistics and that is why we have selected to search two main grammatical cohesive devices: substitution and ellipsis.
The usual task of substitution and ellipsis is to eliminate unnecessary repetition of words, phrases, and clauses. In general, non-native speakers of English fail to understand something they read or hear and this is because they do not understand words being used or words which are not being used. In both spoken and written form, there is a great tendency to either leave out words we think are needless or to use another word instead of another phrase. Failure to understand them can cause considerable confusion to learners, more specifically while speaking. Based on the difficulties that learners are facing, the aim is to determine the structures of these devices in English and Albanian by comparing fiction and nonfiction texts. This study may be useful to many students and researchers who are interested to study or analyze further these two languages.

\section{Literature Review}

The literature review of the present study will try to provide the most relevant published theories on cohesion and the best elaborations of substitution and ellipsis which have attracted the 
attention of many reputable linguists and grammarians. Numerous studies about cohesion and coherence in ESL/EFL writing have been done by using Halliday and Hasan's (1976) framework. The literature review will explore the area of research to get information from recent articles.

Linguists have developed a particular interest in the study of cohesion and its devices, and a significant number of analyses of written texts have continued to concentrate on the recognition and features of coherent devices that enable readers to comprehend a text. Following Halliday and Hassan's work on Cohesion in English, cohesion has gained popularity in discourse analysis studies. Halliday \& Hassan (1976) classified cohesive devices into grammatical cohesive devices (reference, substitution, ellipsis and conjunction) and lexical devices (reiteration and collocation). Faigly (1981, as cited in Yoon Hee Na, 2011) compared the cohesive devices in poor and good writing of college freshmen and found that well-written essays had twice as many instances of reference, conjunction, and lexical collocation. Jabeen et al., (2013) analyzed an act play by Chekhov called "The Bear". Finally, the study of the text's coherent devices showed that discourse or text can only be meaningful when different fragments are taken together to create a single whole. In another study, Azzouz (2009) looked at how grammatical cohesive devices were used in students' writings. A group of 40 secondyear students were asked to compose essays, and a description of their work was performed to see how often they could use grammatical cohesive devices. In conclusion, students demonstrate an ability to use a particular feature in their creative writing. The percentage of less use in substitution was $1.48 \%$ and this was explained in terms of avoidance in that, students tended not to use such type because they do not know how, when, and where can be reached, and the percentage of more use in conjunctions was of $54.05 \%$ which was explained in terms of awareness.

Hoang Tra My (n.d) in his study examined the frequency of the use of cohesive devices in reading texts in English. The total number of cohesion ties used in sixteen passages was 2385 . The use of lexical cohesive devices was much more than grammatical cohesive devices in sixteen passages. According to him, the high frequent use of substitution and ellipsis can make the texts more difficult and complicated to understand and without the knowledge of them, students may misunderstand and misinterpret the text.

In another study, Coskun (2011) evaluated two groups of students. One is made up of 98 immigrants and the other made up of 103 Turkish students. It is concluded that Turkish students had higher averages in all of the ellipsis types compared to the immigrant students. Problems relating to the use of ellipsis are found more frequently in texts written by the immigrant students. The immigrant and Turkish students' averages for using substitution component are less in number and similar to each other. The difference between group averages is not significant. In the student texts, there were no issues found with the use of substitution elements.

\section{Research Methodology}

\subsection{Research Hypotheses}

Through the present study, it is hypothesized that:

H1: Substitution and ellipsis are used more frequently in fiction than in nonfiction texts.

H2: In translated texts from English, substitution changes into ellipsis in Albanian.

H3: Ellipsis occurs more frequently than substitution in both text types.

\subsection{Research Questions}

1. How frequently are substitution and ellipsis used in English and Albanian texts?

2. What are the differences and similarities of cohesive devices when translated from English to Albanian?

3. Which elements form the structures of ellipsis and substitution in English and Albanian?

\subsection{Research Design and Methodology}

This research is an effort to analyze and compare the structures of substitution and ellipsis in English and Albanian. The basic methods used are theoretical, empirical, quantitative and qualitative. Based on the findings of the analysis, the text-forming elements and their characteristics will be analyzed in detail. The overall structure of the paper consists of three parts: The first part presents a general overview of cohesion and its types with selected examples. The second part presents the structure of ellipsis and substitution in English and Albanian. In this part, the translation method will be used to show the form of ellipsis and substitution in both languages. The third part will present the data analysis and interpretation of the use of substitution and ellipsis in English and Albanian.

\subsubsection{Corpus}

The realization of our goal, accurate and clear reflection of classification, and analysis of ellipsis \& substitution is based on rich literature in both languages. Materials used in comparing ellipsis and substitution in English and Albanian are divided into corpus A presenting fiction texts and corpus $\mathbf{B}$ presenting nonfiction texts. Corpus A comprises two novels: one in English and 
one in the Albanian language to analyse the frequency and structures of ellipsis and substitution in fiction texts. We have chosen the novels "Animal Farm" by Orwell (2009) for English and "Sikur të isha djalë" by Stërmilli (1936) for Albanian. On the other hand, corpus B comprises two newspaper articles in English and Albanian to analyse the use of ellipsis and substitution in nonfiction texts. We have chosen daily newspapers "Kosova Sot" (2016) for Albanian and "The Guardian" (2016) for English.

\section{Research Results}

In this chapter, the frequency of ellipsis and substitution are analyzed through fiction and non-fiction texts. Moreover, the elements which form the structures of ellipsis and substitution in English and Albanian are analyzed. The texts chosen for this analysis were: “Animal farm and Sikur të isha djalë” for corpus $A$ and "The Guardian and Kosovasot" for corpus $B$. These two corpora gave the results presented on (tables 1, 2, 3, 4, 5) and in the paragraphs below.

\subsection{Results of Fiction Texts}

In relation to these two cohesive devices used in fiction texts, the following results are found: Table 1 shows that ellipsis is used more in the Albanian language rather than in English. The total number of items is 67 in Albanian and 46 in English. If we look at the division of ellipsis, we can see that nominal and clausal ellipsis in Albanian dominate more than in English. But the predominant one is nominal ellipsis with 34 items in Albanian. Verbal ellipsis ranking the second takes up 18 items in English and 18 in Albanian. Clausal ellipsis comes the third with 8 items in English and 15 items in Albanian. Whereas table 2 shows the number (percentage) of substitution used in both texts where substitution prevails more in English than Albanian, with a total of 25 items in English and 5 items in Albanian. Among the three types of substitution, nominal substitution is the most frequently used device with 11 items in English. Secondly, clausal substitution takes up 10 items in English and 2 items in Albanian. Interestingly, verbal substitution did not occur in Albanian whereas in English with 4 items.

Table 1. The percentage of ellipsis in fiction texts

\begin{tabular}{|c|c|c|c|c|c|c|c|}
\hline \multicolumn{7}{|c|}{ Number of Ellipsis } & \\
\hline & \multicolumn{2}{|c|}{ Nominal } & \multicolumn{2}{|c|}{ Verbal } & \multicolumn{2}{|c|}{ Clausal } & \\
\hline Fiction Texts & $\begin{array}{l}\text { Number } \\
\text { of items }\end{array}$ & $\%$ & $\begin{array}{l}\text { Number of } \\
\text { items }\end{array}$ & $\%$ & $\begin{array}{l}\text { Number of } \\
\text { items }\end{array}$ & $\%$ & Total \\
\hline Animal Farm & 20 & $43 \%$ & 18 & $39 \%$ & 8 & $18 \%$ & 46 \\
\hline Sikur të isha djalë & 34 & $51 \%$ & 18 & $27 \%$ & 15 & $22 \%$ & 67 \\
\hline
\end{tabular}

Table 2. The percentage of substitution in fiction texts

\begin{tabular}{|l|l|l|l|l|l|l|}
\hline \multicolumn{7}{|c|}{ Number of Substitution } \\
\hline
\end{tabular}

\subsection{Results of Non-fiction Texts}

In relation to these two cohesive devices used in non-fiction texts, the following results are found: Table 3 shows that ellipsis is used more in the Albanian language rather than in English in nonfiction texts too. The total number of items is 22 in Albanian and 8 in English. As shown in table 3, among the three types of ellipsis, verbal ellipsis is the most frequently used device with 13 items in Albanian. Nominal ellipsis comes the second with 8 items in Albanian and 2 items in English. Clausal ellipsis presents the lowest frequency of use with only 1 item in Albanian and 0 items in English. 
Table 3. The percentage of ellipsis in non-fiction texts

\begin{tabular}{|c|c|c|c|c|c|c|c|}
\hline \multicolumn{7}{|c|}{ Number of Ellipsis } & \\
\hline & & inal & Ver & & $\mathrm{Cla}$ & usal & \\
\hline Non-Fiction & $\begin{array}{l}\text { Number } \\
\text { of items }\end{array}$ & $\%$ & $\begin{array}{l}\text { Number of } \\
\text { items }\end{array}$ & $\%$ & $\begin{array}{l}\text { Number of } \\
\text { items }\end{array}$ & $\%$ & Total \\
\hline The Guardian & 2 & $25 \%$ & 6 & $75 \%$ & 0 & $0 \%$ & 8 \\
\hline Kosova Sot & 8 & $36 \%$ & 13 & $59 \%$ & 1 & $5 \%$ & 22 \\
\hline
\end{tabular}

The following table (4) shows the number of substitution used in non-fiction texts. The frequency of substitution seems to be the same in both languages with a total of 4 items in English and 3 items in Albanian. The number of nominal and clausal substitution remains the same with 2 items in nominal and 1 item in clausal. Whereas verbal substitution comes with 1 item in English and 0 items in Albanian. Based on the results, substitution is rarely used in non-fiction texts.

Table 4. The percentage of substitution in non-fiction texts

\begin{tabular}{|l|l|l|l|l|l|l|}
\hline \multicolumn{7}{|c|}{ Number of Substitution } \\
\hline
\end{tabular}

Lastly, the total number of ellipsis in fiction texts is 113 and 30 in non-fiction texts which proves that the highest frequency of ellipsis occurs in fiction texts more rather than in non-fiction ones. As shown in table 5, substitution also occurs more often in fiction texts than non-fiction texts. In other words, fiction ones predominate in the use of ellipsis and substitution in both languages.

Table 5. The total number of ellipsis and substitution in fiction and non-fiction texts

\begin{tabular}{|l|c|c|}
\hline \multicolumn{1}{|c|}{ Type of text } & Ellipsis & Substitution \\
\hline Fictions text & 113 & 30 \\
\hline Non-Fiction & 30 & 7 \\
\hline
\end{tabular}

\subsection{The Differences and Similarities of}

\section{Cohesive Devices in Translation}

The second research question was about the differences and similarities of cohesive devices when translated from English to Albanian. Based on the above analysis of grammatical cohesive devices, it is concluded that both English and Albanian besides differences, they also show similarities in the use of cohesive devices. In both languages, ellipsis occurs in its nominal, verbal and clausal form. Nominal ellipsis seems to be the same in
English and Albanian in most of the cases. And it can also remain in the same position.

Sometimes, ellipsis is not appropriate in Albanian as it is in English, so, we must use the omitted word of English in Albanian translation. For example, in the next sentence, we cannot leave the noun universe in translation. Also, in the second sentence, we cannot omit the main verb in Albanian simply because the Albanian sentence structure does not accept ellipsis. Furthermore, 
in clausal ellipsis, the modal verbs help sentences to be shortened whereas in Albanian we do not need modals at all. Another important characteristic (similarity) is the use of ellipsis in the question-answer dialogues. Clausal ellipsis occurred mostly in YES/NO answers in English and Albanian.

As in English, there are just a few substitution words used in texts. The English nominal substitution words one (for singular) and ones (for plural) are very productive words in the English language and their equivalents in Albanian are një/ca which do not have a wide use as substitution devices. For this reason, they turn into ellipsis in translation. On the other hand, the pronoun one/ones can be translated in Albanian with the help of other pronouns such as atë, këtë, ato etc. So, the substitution remains as substitution also in Albanian.

The verbal substitution is also realized through the verb DO which is placed at the end of the clause. But in the Albanian language the verb BËJ is not so fruitful, so we directly use the same main verb rather than substitution with BËJ. The verbal substitution DO can also become ellipsis in Albanian. In this case, you can either translate by using the main verb instead of substitution or you can refer to ellipsis. Another typical occasion of substitution is the adverb SO (kështu, këtë). Generally, it can substitute a clause. In the Albanian, language it becomes ASHTU/KËSHTU and they have the same use in the clauses.

\subsection{Elements which from the Structures of Ellipsis and Substitution in English and}

\section{Albanian}

The last research question was to find out the elements which form the structures of ellipsis and substitution in English and Albanian, more specifically in Albanian. In the corpus in English, nominal ellipsis appeared with pronouns and nouns, adjectives and determiners. Verbal ellipsis is realized through the omission of the main verb, particularly after the modal verb. The verb "to be" was the one which was left out the most in texts. Clausal ellipsis is formed through yes/no answers mostly. In clausal ellipsis the relative pronoun "that" can also be left out. Moreover, in conditional sentences, we can stop the sentence after the "wh" relative pronoun.

It is found out that ellipsis is almost the same in English and Albanian, but with a little difference. In the Albanian corpus, nominal ellipsis is realized through nouns, adjectives and pronouns and the element which was left out mostly in texts was the personal pronoun. Verbal ellipsis is formed with the removal of the verb "to be" most of the time, particularly in newspaper headlines. Different from English, modal verbs (will, would, etc) do not function as ellipsis in Albanian because they need the main verb attached. But the modal verb "MUND" was used to form verbal and clausal ellipsis both. As in English, Clausal ellipsis is formed with yes/no answers. Sometimes, clausal ellipsis is formed by stopping after the main verb (see example 47 in appendix B). One important characteristic in Albanian is the use of quantifiers in verbal and clausal ellipsis (see appendix B).

Substitution was a device which was used rarely in both text types. In the English language, elements which formed nominal substitution were "one, ones, the same, all, both and the two". Verbal substitution was formed with the auxiliary verb do (does, did, done). Clausal substitution was formed with "do and so". On the other hand, Albanian nominal substitution is realized through the words "njëri, tjetri, i pari, i dyti". Verbal substitution did not appear in either of the text types. Lastly, clausal substitution is formed with "ashtu, kështu" which is the same as in the English language.

Conclusively, ellipsis and substitution help in the avoidance of repetition, and they are used more in informal texts than in formal texts. The need to express ideas more accurately and thus avoid confusion, makes us use ellipsis and substitution rarely in formal texts.

\section{Conclusion}

Generally, the study of text and its components has always been a great need for greater success in the written and spoken form of language usage and it has always raised the interest of linguists.

In this research, substitution and ellipsis have been selected as two main grammatical devices in texts. To sum up,

$\mathrm{H} 1$ : the total number of ellipsis in fiction texts is 113 and 30 in non-fiction texts which proves that the highest frequency of ellipsis occurs in fiction texts more rather than in non-fiction ones. Substitution also occurs more often in fiction texts (30) than non-fiction texts (7). In other words, fiction ones predominate in the use of ellipsis and substitution in both languages.

H3: Moreover, the study reveals that ellipsis occurs more frequently than substitution in both text types. Based on this, it can be stated that the need to omit words is higher than the need to replace words in linguistic structures. The omitted linguistic structures are easily understood even though they are not expressed in texts.

Findings of the current study highlighted that $\mathrm{H} 2$ : in translated texts from English, substitution changes into ellipsis in Albanian. The English substitution pronouns one (for singular) and ones (for plural) are very productive words in English language and their equivalents in Albanian are $\boldsymbol{n j} \ddot{e} / \mathbf{c a}$ which do not have a wide 
use as substitution devices. However, they turn into ellipsis in translation.

On the whole, based on the analysed data of grammatical cohesive devices, it is concluded that both English and Albanian besides differences, they also show similarities in the use of cohesive devices. Albanian and English are two languages which belong to different families in the trunk of Indo-European languages. Yet, the results reveal that there are similar rules which enable the phenomenon of cohesion. Consequently, in both languages, ellipsis occurs in its nominal, verbal and clausal form.

\subsection{Recommendations for Further Research}

This study will be a modest contribution in analyzing, comparing and contrasting, and presenting substitution and elliptical structures in the Albanian language. This kind of study is also significant for teachers and students in recognizing characteristic features of substitution and ellipsis which lead one in learning and using these two languages accurately and fluently.

Overall, further research should be done to provide students with the knowledge of cohesion which is considered to be an important means to help them develop their speaking, reading, writing, listening skills. In order to achieve more results in this area, more explorations should be conducted specifically in the Albanian language since this approach has been neglected in Albanian.

\section{References}

1. Akademia e shkencave. (2002). Gramatika e gjuhës shqipe 1 (2nd ed., Vol. 1). Tirane.

2. Academia e shkencave. (2002). Gramatika e gjuhës shqipe 2 (2nd ed., Vol. 2). Tiranë

3. Akpınar, K. (2013). Identifying Discourse Patterns: A Case Study with Turkish Foreign Language Learners. ELT $\begin{array}{llll}\text { Research Journal, } & 1 & \text { (4), 255-277. }\end{array}$ https://dergipark.org.tr/en/pub/eltrj/issue/5476/74394

4. Azzouz, B. (2009). A discourse analysis of grammatical cohesion in student's writing. A case study of second year students, Mentouri University Constantine (Master's dissertation). Mentouri University-Constantine. http://archives.umc.edu.dz/bitstream/handle/123456789/1 1397/AZZ1086.pdf?sequence

5. Bosanac, S \& Latin, D. (2008). Discourse analysis: spoken Language. University of Zagreb. https://www.academia.edu/636652/Discourse Analysis Spoken Language student seminar paper

6. Brown, G \& Yule, G. (1983). Discourse analysis. Cambridge University Press.

7. Carter, R \& Carthy, M. (2006). Cambridge grammar of English (1 st ed.). Cambridge University Press. https://d1wqtxts1xzle7.cloudfront.net/33714575/McCarth
y-Explorations in Corpus-

Linguistics.pdf?1400225960=\&response-content

disposition=inline $\% 3 \mathrm{~B}+$ filename\%3DExplorations_in_C orpus_Linguistics.pdf\&Expires

8. Chomsky, N. (2014). The minimalist program. The MIT Press.

9. Coskun, E. (2011). Cohesion in compositions of Turkish and immigrant students. Journal Articles; Reports Research, 11(2), 892-899. https://eric.ed.gov/?id=EJ927382

10. Cota, L. (2013). Strukturat eliptike dhe roli i komponenteve gramatikor në përcaktimin e elipsës kontekstuale në gjuhët angleze dhe shqipe. (Elliptical structures and the role of grammatical components in determining contextual ellipses in English and Albanian). (Dissertation). University of Tirana. Albania. http://www.doktoratura.unitir.edu.al/wpcontent/uploads/2013/09/Doktoratura-Lutfije-CotaFakulteti-i-Gjuheve-te-Huaja-Departamenti-i-GjuhesAngleze.pdf

11. Crystal, D. (2019). The Cambridge encyclopedia of the English language (3rd ed.). Cambridge University Press. https://doi.org/10.4000/lexis.4512

12. Dibra, V. (1999). Gjuhësi teksti. (Text linguistics). (1 st ed.). Tiranë: SHBLU.

13. Flowerdrew, J. \& Mahlberg, M. (2009). Lexical cohesion and corpus linguistics (1st ed.). John Benjamin's Publishing Company. Retrieved from https://books.google.com/books?hl=en\&lr=\&id=kFZdJV $\underline{4 \text { sq5 AC\&oi }=\text { fnd } \& p g=P P 1 \& d q=F l o w e r d e w ~},+\mathrm{J} .+\% 26+\mathrm{M}$ ahlberg, + M.+(2009).+Lexical+cohesion+and+corpus+lin guistics.+Amsterdam:+John+Benjamin. \&ots=52Sf45xZ $\underline{\text { Kd\&sig=6cJvr5xs10zeV6vJKnxusg4SUNU\#v=onepage }}$ $\underline{\& \mathrm{q} \& \mathrm{f}=\text { false }}$

14. Greenbaum, S. Quirk, R. (1993). A student's grammar of English language (1 st ed.). Longman.

15. Halliday, M.A, \& Hasan, R. (1976). Cohesion in English (1 st ed.). England: Longman.

16. Hameed, H. (2008). Cohesion in texts: a discourse analysis of a new article in a magazine. Al faith journal. No.37. Diyala University. https://www.researchgate.net/publication/328216143_Co hesion_in_TextsA_Discourse_Analysis_of_news_Article in_a_Magazine

17. Hart, C. (2005). Doing your master dissertation (1 st ed.). SAGE publication.

18. Hazout, I. (1995) Comparative Ellipsis and logical form. Nat Lang Linguist Theory 13, 1-37. https://doi.org/10.1007/BF00992777 
19. Hee, Y. Na. (2011). Cohesive devices in CMC texts produced by American and Korean EFL writers. Linguistic Research 28(3), 743-771, 3, 1-10. http://isli.khu.ac.kr/journal/content/data/28_3/14.pdf

20. Jabeen, I. Mehmood, A. Iqbal, M. (2013). Ellipsis, reference, substitution as cohesive devices. Academic Research International, 4(6), 1-9. http://www.savap.org.pk/journals/ARInt./Vol.4(6)/2013( 4.6-15).pdf

21. Leech, G. N. (1985). Principles of pragmatics. Retrieved from

https://books.google.com/books?hl=en \&lr=\&id=2uWXC wAAQBAJ\&oi=fnd $\& p g=$ PP1 \&dq $=$ Leech,+ G.+(1989).+ Principles+of+pragmatics:+Longman.\&ots $=\mathrm{KBkXthCoU}$ $q \& \operatorname{sig}=\operatorname{ImpCIsKA-}$ mCI2S7le6GWZLUDZRw\#v=onepage \&q\&f=false

22. Leech, G. N., \& Svartvik, J. (1994). A communicative grammar of English. Longman Publishing Group.

23. Martin, J. R. (2015). Cohesion and texture. The Handbook of Discourse Analysis, 6181. https://doi.org/10.1002/9781118584194.ch3

24. Martinet, A. (2002). Elemente të gjuhësisë së përgjithshme. (Elements of general linguistics). (1st ed.). Dituria.

25. Merchant, J. (2001). The syntax of silence: Slucing, islands and the theory of ellipsis. Oxford University Press.

26. MU, I. (n.d). Cohesive devices in open and closed registers.

http://is.muni.cz/th/271316/ff_m/Cohesive_Devices_in_ Open_and_Closed_Registers_MT.pdf

27. Nariyama, S. (2004). Subject ellipsis in English. Journal of Pragmatics, 36(2), 237-264. https://www.sciencedirect.com/science/article/abs/pii/S0 $\underline{378216603000997}$

28. Nuhiu, V. (2002). English syntax. Univeristy of Prishtina.

29. Nunan, D. (1993). Introducing discourse analysis. Penguin Books.

30. Orwell, G. (2009). Animal Farm. Transaction Publishers.

31. Querol, M. (2003). Substitution as a cohesive device of grammatical cohesion in English narrative and its translation into Spanish. http://www.uji.es/bin/publ/edicions/jfi9/fang/5.pdf

32. Stërmilli, H. (2002). Sikur t'isha djalë. Letrat Publishing. Albania.

33. The Guardian. http://www.ngrguardiannews.com/ (2015).

34. Tra My, H. (n.d). An analysis of cohesive devices in reading texts in English 11. http://tainguyenso.vnu.edu.vn/jspui/bitstream/123456789 139481/1/TT 04051000567.pdf
35. Widdowson, H. G. (1978). Teaching language as communication. Oxford University Press.

36. Witte, S. P., \& Faigley, L. (1981). Coherence, cohesion, and writing quality. College Composition and Communication, 32(2),

189. https://doi.org/10.2307/356693

37. Yule, G., \& Widdowson, H. G. (1996). Pragmatics. Oxford University Press. 